\title{
The costs and benefits of duality: Colombia's decentralization and the response to the COVID-19 pandemic
}

\author{
Ricardo A. Bello-Gomez ${ }^{1}$ \\ Pablo Sanabria-Pulido ${ }^{23}$ \\ ${ }^{1}$ Texas Tech University / Department of Political Science, Lubbock / TX - United States \\ 2 Universidad de los Andes / School of Government, Bogota - Colombia \\ ${ }^{3}$ Centro de Investigación y Docencia Económicas - CIDE / Public Administration Division, Ciudad de México - México
}

Colombia's duality between the relative strength of the central government and the broad process of decentralization towards subnational and local governments has shaped the country's response to the COVID-19 pandemic. Substantial tensions have arisen between the national and subnational governments in the handling of the crisis. Thus, blurred policy boundaries challenge multi-level government coordination. Yet, intergovernmental relations and multi-level governance have worked at some extent. Meanwhile, leadership styles, the level of political support, the local governance environment and the level of local institutional capacity have affected the strategies of local government leaders and their success to tackle the pandemic. Moreover, uneven healthcare capacity across the Colombian territory posits further challenges for a national response to the pandemic that ensures both effectiveness and equity.

Keywords: COVID-19; decentralization; intergovernmental relations; government capacity; Colombia; multilevel governance.

\section{Custos e benefícios da dualidade: a descentralização da Colômbia e a resposta à pandemia de COVID-19}

A dualidade da Colômbia, entre a força relativa do governo central e o amplo processo de descentralização com fortalecimento de governos subnacionais e locais, estabeleceu os contornos da resposta do país à pandemia de COVID-19. Testemunhou-se uma substancial tensão entre os governos nacional e subnacionais no tratamento da crise. Os limites pouco claros das políticas desafiam a coordenação governamental em vários níveis. No entanto, as relações intergovernamentais e a governança em vários níveis funcionaram até certo ponto. Enquanto isso, os estilos de liderança, o nível de apoio político, o ambiente local de governança e o nível local de capacidade institucional, afetaram as estratégias das lideranças governamentais locais e seu sucesso no combate à pandemia. Além disso, as desigualdades na capacidade de prover serviços de saúde em todo o território colombiano apresentam desafios adicionais para uma resposta nacional à pandemia que garanta efetividade e equidade.

Palavras-chave: COVID-19; descentralização; relações intergovernamentais; capacidade governamental; Colômbia; governança multinível.

\section{Los costos y efectos de la dualidad: descentralización en Colombia y la respuesta a la pandemia de COVID-19}

La dualidad del modelo unitario descentralizado de Colombia, entre la fuerza relativa del gobierno central y el amplio proceso de descentralización hacia los gobiernos subnacionales y locales ha influido en la respuesta del país frente a la pandemia de COVID-19. Algunas tensiones sustanciales han aparecido entre los gobiernos nacional y subnacionales en el manejo de la crisis. Un contexto con algunos límites jurisdiccionales borrosos impone un reto a la coordinación gubernamental multinivel. Sin embargo, las relaciones intergubernamentales y la gobernanza multinivel parecen haber funcionado en alguna medida. Por otro lado, los estilos de liderazgo, el nivel de apoyo político, el entorno local de gobernanza y el nivel local de capacidad institucional han afectado las estrategias de las autoridades locales y su éxito al enfrentar la pandemia. Más aun, las disparidades en la capacidad de protección en salud a lo largo del territorio colombiano plantean desafíos adicionales para una respuesta coordinada nacional a la pandemia que asegure tanto efectividad como equidad.

Palabras clave: COVID-19; descentralización; relaciones intergubernamentales; capacidad institucional; gobernanza multinivel; Colombia. 


\section{INTRODUCTION}

Effective crisis responses often demand clearly defined roles and fluid collaboration in multi-sectoral networks (Comfort \& Kapucu, 2005; Kapucu, 2005). Thus, the COVID-19 pandemic is not an exception to this demand, for it has tested the strength and fine tuning of governance systems all around the world. In the case of Colombia, a self-defined unitary decentralized country, the governance system is characterized by the pivotal role of the central government even though the country has experienced a substantial process of decentralization over the last few decades (Falleti, 2010; Sanabria, 2019). Thus, subnational and local governments have gained further spaces of responsibility, power and resources for policy making and implementation, and service provision. This study will expose the advantages and costs of Colombia's intergovernmental relations system. Amid the crisis, political leaders and public opinion have debated whether the national or local governments should take the leading voice in addressing the current public health and socioeconomic crisis. They have eventually adjusted and advanced towards some degree of coordinated response. Then, two main challenges of this multi-level governance arrangement are presented. First, local government response and effectiveness rely on particular context characteristics, the quality of the local governance environment and the local leadership style. Second, the profound unevenness in government capacity across the country requires that the Colombian central government actively addresses these imbalances through local capacity building and resource equalization.

\section{DECENTRALIZATION AN INTERGOVERNMENTAL RELATIONS IN COLOMBIA}

Colombia epitomizes a particular combination of centralism and decentralization in terms of administrative, fiscal, and political structure, which might appear sui generis, even in the Latin American context. Such specific mixture has elicited some tensions between the national and subnational levels of government that have apparently become more evident since the COVID-19 pandemic erupted. In the Colombian context, subnational governments, and municipalities in particular, have a wide array of competencies. The greater role that municipalities have played after the 1991 constitution, vis-a-vis the national level, has probably eased the appearance of new opportunities for clashes between the national and subnational governments in the country. Such tensions are possibly the result of the path dependence that has set the particular multilevel governance arrangement that exists in the country. We explore such arrangement in this work.

Colombia's multilevel governance has, during the last three decades, developed a more interactive intergovernmental relations setting (Sanabria, forthcoming). After the 1991 constitution the municipal level of government came out as a net winner of the new decentralized institutional arrangement (Sanabria, 2019), bringing more room for IGR bargaining and tensions. Yet, in the same period, the country has seen a rapid (but highly heterogeneous) development of institutional capacity, particularly in the most populated cities and their metropolitan areas.

The palpable disparities in development appear to feed the tensions between government levels. Figure 1 presents the distribution of the Human Development Index (HDI) across Colombia in 2018. Regions such as Bogotá, Antioquia, Valle del Cauca, Santander and Cundinamarca exhibit levels of development neighboring those of developed countries, where areas such as the Pacific coast, most 
provinces of the Caribbean coast and the peripheral areas of the Amazon and Orinoco basin show very low levels of institutional capacity and development. The HDI reveals the largest gaps for the bordering areas and the coastal provinces. Furthermore, those gaps appear to be worsening as time progresses.

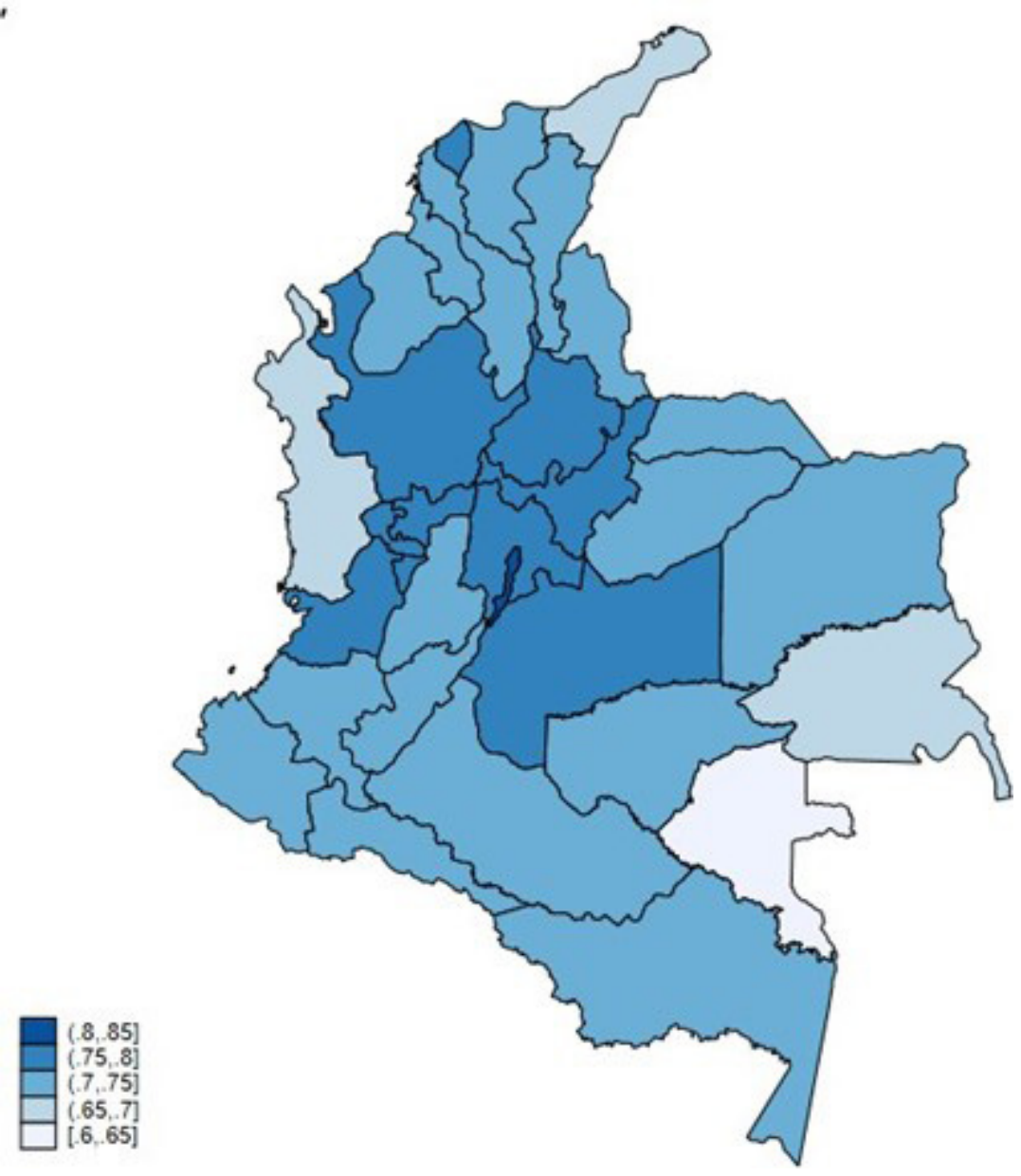

Source: Elaborated by the authors.

This heterogeneity has encouraged the most developed (and most competitive) areas to become more active in demanding greater autonomy and further discretion in policy making. Hence, although the decentralization was proposed as a means to encourage the more concurrent development of the most disadvantaged regions, the country still has a pending agenda in order to achieve convergency in institutional capacity and State presence, particularly in the peripheral areas. To some extent, the COVID-19 emergency exposed the institutional capacity gaps in those areas.

Overall, Colombia has witnessed a rapid development during the last three decades. A polycentric model of development with four main urban centers (the capital district of Bogotá, the city of Medellín and its surrounding metropolitan area in the North West part of the country, the cities of Santiago de 
Cali in the South West, and Barranquilla in the Caribbean North) has distributed regional powers, but has also concentrated institutional capacity. Furthermore, the new roles granted by the constitution to the smaller municipal units has implied greater chances for tensions with the national level of government. Municipal leaders and public servants, and the population in general, often perceive the national government, strongly centered around the leadership of the President of Colombia, as more technically sophisticated compared to the subnational governments (Avellaneda \& Bello-Gomez, 2020).

The greater powers granted by the 1991 constitution to the municipalities, the existent model of fiscal federalism, and the greater institutional capacity of some subnational units, has come sometimes at the expense of the preeminence of the national authorities. What is more, in some policy domains, the national government appears increasingly to play a tributary role vis-à- vis the mayors of the largest cities. Thus, it is not surprising that the Presidency of the Republic, amid the emergency of COVID-19, issued a decree that explicitly declared the superiority of the national guidelines over the departamento and municipal ones. This action indicates the stressed state of intergovernmental relations during the beginning of the pandemic, which we explain in the next section.

\section{TENSIONS BETWEEN NATIONAL AND SUBNATIONAL RESPONSES AMID COVID-19}

In this context, intergovernmental relations in Colombia often portray an active interplay of bargaining, persuasion, coaction, and negotiations between the three levels of government, likely to elicit sporadic clashes amid a strong presidential system. The clashes were particularly salient at the beginning of the pandemic regarding aspects such as the intensity of the lockdown, the closing of schools, airports and public transport, among others. Thus, the COVID-19 response initiated with not few situations of potential clashes in multilevel governance. The arrival of COVID-19 prompted eager responses from subnational governments that were often misaligned with the broad guidelines offered by the national government. The misalignment provoked reactions from the national level of government, and even public tensions between some mayors and the president. The rise and intensity of the clashes varied according to factors such as the level of institutional capacity of the subnational government in question, the political identification with the president, and the prospective political agenda of the mayors of the larger cities. However, it is worthy to mention that the subsequent development of the pandemic showed a high level of compliance with the national guidelines and acquiescence with the orders of the national government by the subnational governments.

Yet, the most visible tensions have occurred between the President, Iván Duque, and the Mayor of Bogotá, Claudia López, mainly regarding the speed and the scope of the COVID-19 response (Semana, 2020a). As Ramirez de la Cruz, Sanabria, Grin, Cravacuore and Orellana (2020) illustrate, the evidently different approaches between the two leaders at the beginning of the pandemic triggered a series of public accusations of undue intervention into the competencies and the scope of the actions of each other's government. Although the tensions have ceased or at least appeased, this was not the same experience of other subnational leaders who have appeared to play a more strategic approach. For instance, the Mayor of Medellín, the governor of Antioquia, and the national government itself have publicly expressed there is a highly collaborative relationship between the three levels.

Thus, not surprisingly, the institutional arrangement of intergovernmental relations, alongside other political and institutional capacity factors, appear to have affected the quality of the articulation 
in the responses to COVID-19 between national and subnational governments in Colombia. The different types of interaction, ranging from conflict to cooperation, have denoted that collaborative behaviors matter, even more amidst a stringent emergency as the current one (Sanabria, 2020). The comparison between these two cases might imply that local government responses to the COVID-19 pandemic demand the development of strategic relationships amid a multilevel governance system such as the case of Medellín (Semana, 2020f). Yet, other aspects of the local management equation in the COVID-19 response need to be included; we move towards such analysis in the next section.

\section{LOCAL GOVERNMENT CAPACITY, LEADERSHIP AND GOVERNANCE FOR COVID-19 RESPONSES}

Colombian local governments' capacity for emergency management, public health and health provision is a key factor in their responses to the COVID-19 pandemic. Beyond these technical characteristics, however, effective crisis management also needs governance capacity and legitimacy (Christensen, Lægreid \& Rykkja, 2016). Complex policy issues require clear institutional arrangements involving actors from government, the civil society and the private sector (Kopell, 2010; Lynn, Heinrich \& Hill, 2001; Sanabria, 2020). Amid a crisis, clearly established governance rules enable actors to effectively exchange information and coordinate actions, thus leading to a proper crisis response (Comfort \& Kapucu, 2005; Kapucu, 2005).

Even though the initial response in Colombia apparently showed some degree of discoordination between the national and subnational governments, the later evolution of the responses has exhibited more synchronization. Yet, local government experiences have differed and demonstrate the importance of local capacity and intergovernmental relations management. The cases of the four largest cities in Colombia - Bogotá, Medellín, Santiago de Cali and Barranquilla - allow to explore some relevant elements of governance, capacity and leadership during the pandemic's response. Mayors of these four cities were elected in October 2019 in very different circumstances. For instance, Jaime Pumarejo was elected Barranquilla's mayor with $62.4 \%$ of the votes. This is the fourth consecutive election won by the same political group, the Char family. Pumarejo enjoys not only the support of most of the political groups in the city, but also inherited high popular approval and the well-functioning relationships that his predecessors, particularly mayor Alex Char, established with the business elite (Semana, 2020g).

Meanwhile, Claudia López won the mayoral election of Bogotá by a narrow margin, obtaining $35.2 \%$ of the votes against $32.5 \%$ of her closest contender. She proposed a platform of political renovation, anti-corruption reform, and citizen participation. Since the election, López has worked on establishing communication channels with civil society organizations, and political actors beyond her electoral coalition (Osorio, 2020). Similarly, Daniel Quintero won a close and polarizing election in Medellín (38.6\% versus 29.9\%), after emerging as the most competitive alternative to the right-wing Democratic Center, the party leading the national government. Quintero inherits a two-decade process of local transformation based on good governance principles, progressive urban development, and social innovation (Uran, 2010; Zamudio \& Barar, 2014; Sanabria, 2017). Finally, Jorge Iván Ospina was elected for a second non-consecutive mayoral term in Santiago de Cali. He had ruled the city between 2008 and 2011. Even though Ospina won by a considerable margin of votes (37.9\% versus 25.4\%), he has faced a strong opposition in his return to city government both among political and business sectors.

Brazilian Journal OF PUblic administration ｜ Rio de Janeiro 55(1): 165-179, Jan. - Feb. 2021 
These mayors took a similar approach during the initial stage of the pandemic by implementing containment measures such as lockdowns and severe restrictions to mobility, fundraising for emergency response, and developing strategies for increasing testing, healthcare and welfare capacity. Yet, by the end of April, the pandemic advanced at substantially different paces. Figure 2 shows the daily number of registered COVID-19 cases per million people in each city as a 7-day moving average. Figure 3 presents the daily number of deaths with an associated COVID-19 cause per million people.

\section{FIGURE 2 DAILY COVID-19 CASES PER MILLION PEOPLE}

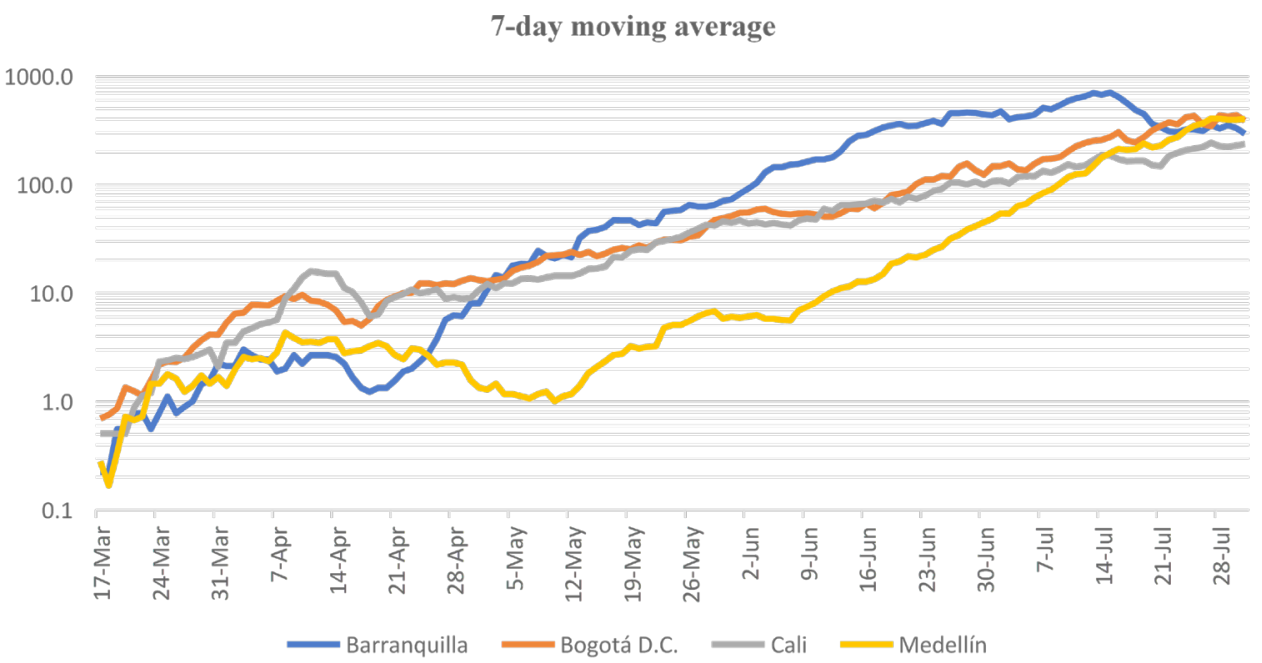

Source: Elaborated by the authors.

\section{FIGURE 3 DAILY COVID-19 DEATHS PER MILLION PEOPLE}

7-day moving average

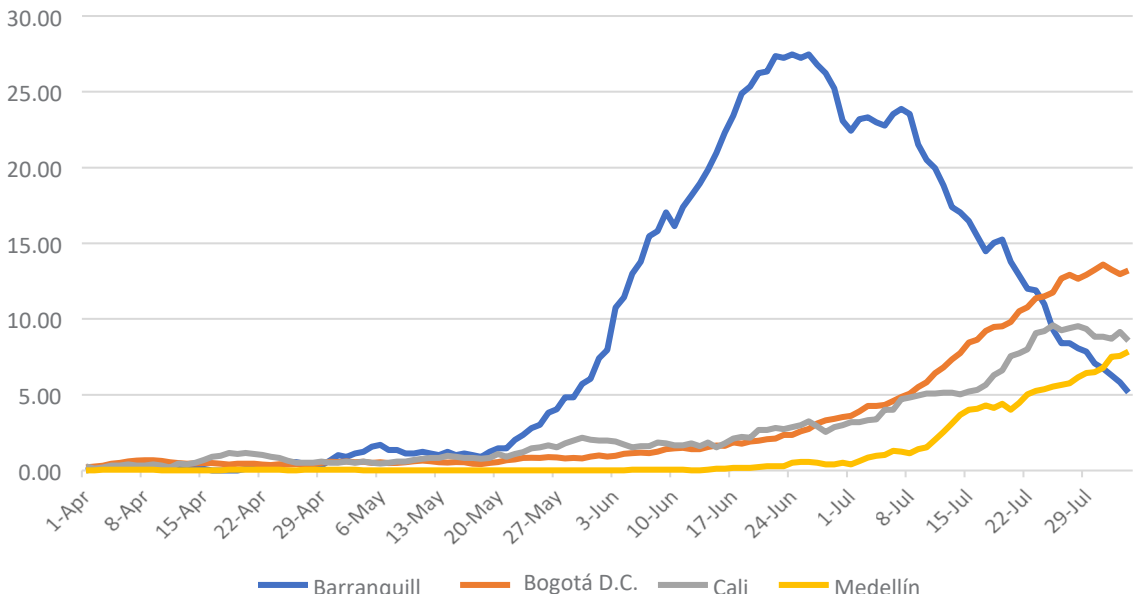

Source: Elaborated by the authors. 
By May, citizens in Bogota overwhelmingly supported mayor López's projected gravitas and bold reactions to the pandemic, even confronting the president (López, 2020) while mayor Quintero's use of data-driven track-and-tracing systems and a fine-tuned network of public, private, and civic actors was praised in Medellin (Arias, 2020). Meanwhile, Barranquilla faced a rapid increase in the number of cases and deaths. Some have pointed out the inconsistency of the Barranquilla government's message which led to increasing citizen dissatisfaction (Semana, 2020c), while the government also focused on blaming citizens' lack of compliance for the crisis (Velásquez \& Molinares, 2020). Between the end of June and mid- July, Barranquilla reached a peak of cases and deaths, becoming the focus of the pandemic in Colombia. The situation has improved substantially afterwards, with mayor Pumarejo (2020) reporting no "extra deaths" beyond the usual death rate in the city by August $1^{\text {st }}$.

The four main cities of Colombia have consistently increased in both cases and deaths per capita amid compliance challenges driven by economic need and misinformation. Yet, recent trends show different evolutions by city. Bogota has maintained a growing trend whereas Barranquilla apparently reached its peak and slowed down, and Santiago de Cali seems to start trending towards lower levels of contagion. Meanwhile, Medellin lost its remarkable track of containment by the end of June with cases rapidly increasing. Public health experts have blamed the national VAT (Value Added Tax) exempted holiday as a factor boosting agglomerations and contagions (Jiménez, 2020). By the end of July and beginning of August, while Barranquilla has passed a first peak and the infection rate seems to be slowing down in Cali, Bogota and Medellin remain at a pace of 200-400 cases per million people identified each day. At this time, the different administrations have opted to shift towards controlled reopening of certain services and localized lockdowns as attempts to make the containment measures more palatable to the people, and thus more effective overall.

As a final consideration, it is important to notice that some salient differences remain in the cities' reliance on experts and data-driven evidence for the control of the pandemic. The administrations of Bogota and Medellin have mostly counted on Colombian epidemiologists and public health experts from national and international universities for advice on containment, testing and tracing. In contrast, Barranquilla's Pumarejo exhibited a belief in herd immunity when he suggested the only way out of the crisis was to aim for a well-paced contagion for the overall population (Velásquez \& Molinares, 2020). Consequently, his administration placed more emphasis in increasing intensive care capacity and downplayed other measures. Finally, Cali's Jorge Iván Ospina, a physician by profession, has provoked a salient debate in the country for his endorsement of antiparasitic Ivermectin as a therapy for COVID-19 (El Tiempo, 2020). While the drug has been amply used in animals and humans, there is no concluding evidence on its effects over the novel coronavirus and COVID-19 (Food and Drug Administration [FDA], 2020).

\section{CHALLENGES OF UNEVEN HEALTHCARE CAPACITY}

The response to COVID-19 has certainly tested the strength of the multilevel governance arrangement of the country, but also the distribution of institutional capacity between the national and subnational governments. It has also shown some strengths of the country's "unitary decentralized" system. For instance, in terms of COVID-19 testing, the national government has set the guidelines and provided technical support to subnational governments from the National Institute of Health (INS for its 
Spanish acronym) whereas the implementation of the COVID-19 testing strategy has been left mainly in the hands of the municipal and departmental governments. Local governments have launched and gradually incremented the number of testing centers. Also, the public supply of testing centers has been complemented with the capacity of private sector labs (private providers, universities and research centers among others) which are free to offer COVID-19 testing but they are restricted to operate only when the user shows a prescription and when there are signs of a potential COVID-19 infection (Semana, 2020h).

Across the Colombian territory, capacity for policy implementation and service provision varies rather substantially (Sanabria, 2019). Thus, national government agencies show different levels of financial and human resources affecting their performance (Bello-Gomez, 2020) while local governments exhibit varied levels of capacity to collect taxes and provide social services (Avellaneda, 2009a, 2009b). The number of intensive care unit (ICU) beds is a particularly relevant measure of capacity for the case of the COVID-19 pandemic. Figure 4 presents a scatter plot of the total number of COVID-19 deaths per million in each departamento by August 17, versus the number of adult ICU beds per million officially recorded by the end of April. Departamentos present a dispersed distribution in their intensive care capacity, ranging from 0 to almost 200 ICU beds per million people.

\section{FIGURE 4 COVID-19 PANDEMIC INTENSITY V. HEALTHCARE CAPACITY}

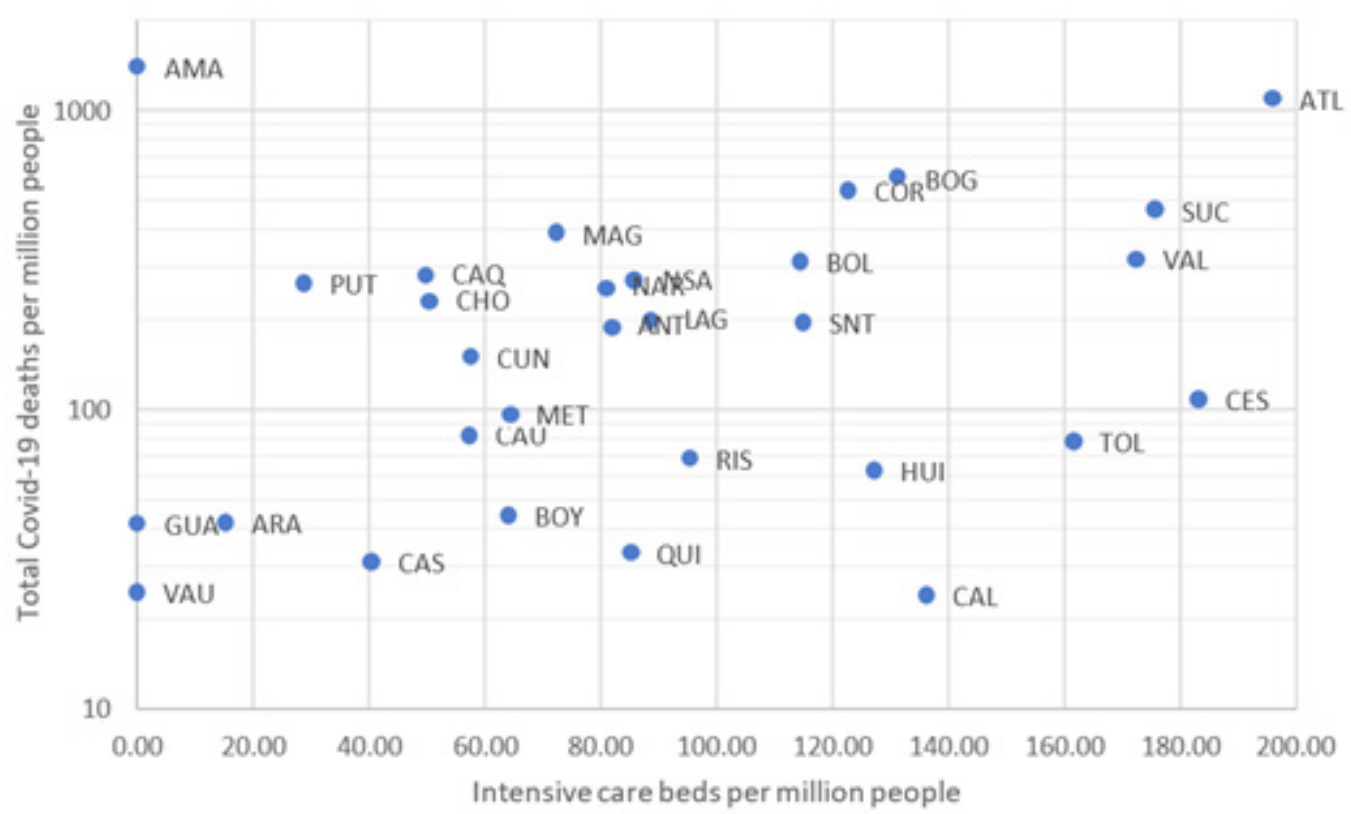

Note: COVID-19 cases by May 26, 2020 and Intensive care beds by August 17, 2020.

Source: Elaborated by the authors. 
Amazonas registers the highest number of COVID-19 deaths per capita in the country. This departamento, located in the Amazon forest, is fully isolated from the rest of the country except by airplane flights to its capital city. By the end of April, the entire departamento lacked intensive care units at all. Meanwhile, donations have recently secured some ventilator units (Sostenibilidad Semana, 2020). Vaupés is also located in the Amazon forest and exhibits a COVID-19 outbreak with null intensive care capacity. In both cases, regional and local governments are facing the influx of COVID-19 cases from Brazil (Ministerio de Salud, 2020), with poor healthcare capacity and the logistical inability to reach for help from neighboring departamentos.

The intervention of the national government becomes paramount to mitigate the sanitary crisis in these regions. Indeed, the Colombian Air Force has already transported critical patients from Amazonas to Bogota to receive intensive care (Vanguardia, 2020). Furthermore, all other departamentos in the bottom quartile of intensive care capacity (see figure 4) are also located in the peripheral areas of the country such as the Pacific coast and the Amazon and Orinoco basins (Guaviare, Guainía, Vichada, Arauca, Chocó, Caquetá and Putumayo), and most of them share an international border. As mentioned before, there peripheral regions also suffer a systematic lack of attention from the national government that has led to their lagged development path (see for instance HDI reported in figure 1). The Colombian government faces the challenge to quickly help these departamentos boost their capacity before a new outbreak occurs.

Another salient issue confronting particular regions of Colombia is the migration crisis emanating from Venezuela. During the last 5 years, Colombia has received about 1.5 million Venezuelans, and at least another million have passed through the country aiming to reach other final destinations (Ministerio de Relaciones Exteriores de Colombia, 2018). Now, amid the rising unemployment levels caused by the COVID-19 pandemic, many Venezuelan migrants have attempted to go back to their country (Carvajal, 2020). However, international borders have remained closed during the pandemic and only a restricted humanitarian corridor allows for safe passage (Kolster, 2020). This situation has led to the rise of migrant population levels in Colombian cities bordering Venezuela, and particularly in Cúcuta, the largest bordering city and the sixth most populated in the country. These cities, therefore, add overcrowding and demanding logistics to the challenge of addressing the pandemic.

While testing is another relevant measure of response capacity, it is highly correlated with the number of cases and deaths, at least in the Colombian case ( 0.90 and 0.83 respectively). This fact possibly suggests that testing has increased as a response to the local intensity of the pandemic. Alternatively, positivity rates allow to assess the extent of testing in a territory. Figure 5 presents aggregate gross positivity rates - the share of positive tests out of the total number of tests - for Colombian departamentos and Bogota. Most of the isolated regions of the Eastern Plains and Amazon Basin present rates below $18 \%$. While these numbers are yet lacking ${ }^{1}$, they do reflect some effectiveness by the national government in boosting local capacity in these regions.

\footnotetext{
${ }^{1}$ The World Health Organization recommends a positivity rate below 5\% before reopening (Dowdy \& D'Souza, 2020).
} 


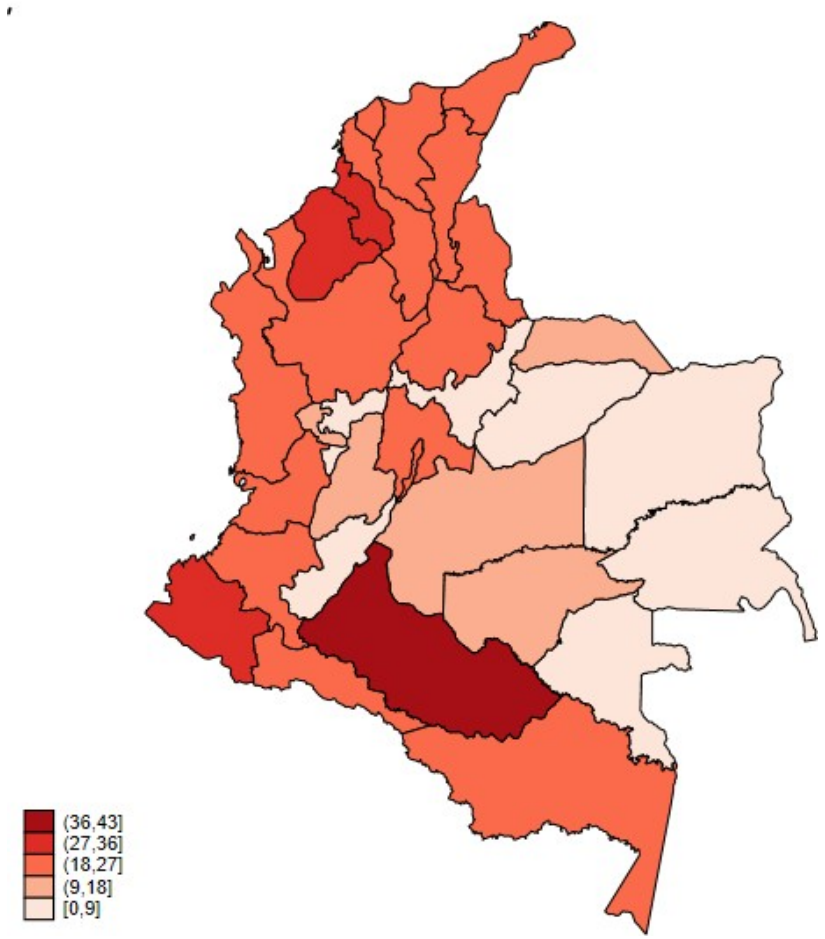

Source: Elaborated by the authors.

Nevertheless, some clusters deserve special attention. The northern departamentos of Córdoba and Sucre report positivity rates of $32 \%$ and $28 \%$ respectively and are among the top regions in COVID-19 deaths per capita. Therefore, the outbreak there is far from being controlled. Meanwhile, the southern departamento of Caquetá, in the Amazon basin, exhibits a positivity rate of $42 \%$. A rising number of deaths and accessibility difficulties make this case of particular concern to avoid an outbreak similar to that of Amazonas in April.

While uneven capacity is salient across departamentos, there is also a substantial problem of concentration of capacity in departamento capitals and larger cities. Acknowledging this problem, the Colombian government has promoted the design and implementation of "integral networks of health service provision" (Ministerio de Salud, 2016). In this process, departamento governments play a key role in the identification of both local healthcare capacity and potential demand, and the articulation of public and private health providers within the network (Ministerio de Salud, 2016). Nevertheless, the healthcare response to the COVID-19 pandemic requires specialized medical equipment such as those in intensive care units, which are even more geographically concentrated in the largest urban centers.

Indeed, intensive care units are located in 81 large municipalities while 39\% of the Colombian population, or 18.8 million people, lives in the remaining 1,041 municipalities where there are 
no ICU beds. This means that any person in these territories requiring intensive care will need ambulance transportation to a different municipality. Table 1 reports the number of people living in municipalities with no ICU beds by the number of ambulances available in each municipality. Over 11 million people live in territories with 3 or less ambulances where even a mild COVID-19 outbreak can put the fragile healthcare system at risk. Thus, these regions demand a high level of operational coordination between departamento and municipal governments to facilitate residents' access to health services during the pandemic.

\section{TABLE 1 AVAILABILITY OF AMBULANCES IN COLOMBIAN MUNICIPALITIES WITHOUT ICU BEDS (APRIL 23, 2020)}

\begin{tabular}{cccc}
$\begin{array}{c}\text { Ambulances / } \\
\text { municipality }\end{array}$ & Total population & $\begin{array}{c}\text { Number of } \\
\text { municipalities }\end{array}$ & Average municipal population \\
\hline $\mathbf{0}$ & 561,337 & 69 & 8,135 \\
$\mathbf{1}$ & $2,264,744$ & 268 & 8,451 \\
$\mathbf{2}$ & $4,355,689$ & 311 & 14,005 \\
$\mathbf{3}$ & $4,038,463$ & 189 & 21,368 \\
$\mathbf{4}$ & $2,613,168$ & 90 & 29,035 \\
$\mathbf{5}$ & $1,361,760$ & 46 & 29,603 \\
$\mathbf{6}$ & 921,790 & 26 & 35,453 \\
$\mathbf{7}$ & 592,981 & 13 & 45,614 \\
$\mathbf{8}$ & 420,904 & 7 & 60,129 \\
$\mathbf{9}$ to 46 & $1,742,672$ & 22 & 79,212 \\
\hline Total & $18,873,508$ & 1041 & 18,130 \\
\hline
\end{tabular}

Source: Elaborated by the authors.

\section{CONCLUSION}

Colombia's response to the COVID-19 emergency displays an interesting case for the analysis of intergovernmental relations in a unitary but decentralized. The national level of government, a powerful executive branch in a strong presidential system, upholds most of the power to make key decisions in a public health emergency like the current one. However, the scope of the situation has highlighted, for all levels of governments, the need of bargaining and collaboration. This institutional framework, while providing further competencies to the municipalities, has elicited some sort of (predictable?) confrontation with the coordination goals of the central government. However, those tensions have vanished in a relatively easy manner in the context of the COVID-19 emergency. On the other hand, although centralism, and the preeminent role of the executive branch have powerfully emerged in the context of the emergency, the national level of government has also recognized the need to collaborate 
with subnational governments in order to ensure policy effectiveness and goal convergence towards the management of the pandemic.

A comparison between the largest cities of the country highlights the importance not only of multilevel government coordination, but also of an integrating and broad-reaching local governance environment with local institutional capacity. The dissimilar pandemic patterns of Bogota, Medellin, Santiago de Cali and Barranquilla reveal how the COVID-19 pandemic has deeply tested local governments' capacity and the quality of their relations with the national government. Beyond solid local capacity, the pandemic has remarked the importance of crucial managerial skills for responding to a system-wide crisis. Such skills include adequate analysis of the political environment, the strategic intergovernmental management, and a wide governance perspective to effectively interact with civil society and the citizenry to ensure citizen compliance and coproduction.

The role of the national government in ensuring an orderly national response to the pandemic is particularly salient in the peripheric areas. Institutional and administrative capacity are unevenly distributed across Colombia and socio-economic conditions are particularly difficult in the peripheric Pacific, Amazon and Orinoco regions. The COVID-19 pandemic has further revealed the precarious presence of the Colombian state in those less developed regions, and its implications for emergency management and public health. Therefore, both peripheric departamentos and small municipalities should be at the top of the priorities for the national government to avoid pandemic outbreaks that can easily turn out of control.

Frequently, different political and social actors criticize the constitutional arrangement of Colombia as a "unitary but decentralized" republic. However, the evolution of the response to the COVID-19 pandemic shows that the apparently dual system might work to build a coordinated and effective intergovernmental strategy. Institutional and administrative capacity, managerial skills and governance environment play a substantial role at the local level in achieving such coordination with the national government amid a complex multilevel governance structure. 


\section{REFERENCES}

Arias, J. M. F. (2020). Alcalde de Medellín Daniel Quintero habla sobre medidas contra coronavirus. El Tiempo. Retrieved from https://www.eltiempo. $\mathrm{com} / \mathrm{colombia/medellin/alcalde-de-medellin-}$ daniel-quintero-habla-de-medidas-contracoronavirus- 492260

Avellaneda, C. N. (2009a). Mayoral quality and local public finance. Public Administration Review, 69(3), 469-486.

Avellaneda, C. N. (2009b). Municipal performance: does mayoral quality matter?. Journal of Public Administration Research and Theory, 19(2), 285-312.

Avellaneda, C. N., \& Bello-Gomez, R. A. (2020). Policy Analysis for Decision Making in Colombian Local Governments. In P. Sanabria, \& N. Rubaii (Eds.), Policy Analysis in Colombia. Bristol, UK: Policy Press, University of Bristol.

Bahl, V. (2012). Murder capital to modern miracle? The progression of governance in Medellin, Colombia. Development Planning Unit (Working Paper No. 143). London, UK: The Bartlett, University College London.

Bello-Gomez, R. A. (2020, May). Interacting Capacities: The Indirect National Contribution to Subnational Service Provision. Public Administration Review. Retrieved from

https://doi.org/10.1111/puar.13192

Carvajal, A. (2020e). Más de 34.000 migrantes han llegado a Cúcuta para cruzar a Venezuela. $E l$ Tiempo. Retrieved from https://www.eltiempo. $\mathrm{com} /$ colombia/otras-ciudades/regreso-demigrantes-venezolanos-a-su-pais-por-la-crisisdel-coronavirus- 484642

Christensen, T., Lægreid, P., \& Rykkja, L. H. (2016). Organizing for crisis management: Building governance capacity and legitimacy. Public Administration Review, 76(6), 887-897.

Comfort, L. K., \& Kapucu, N. (2006). Interorganizational coordination in extreme events: The World Trade Center attacks, September 11, 2001. Natural hazards, 39(2), 309-327.

Dowdy, G., \& D'Souza, G. (2020, August 10). COVID-19 Testing: Understanding the "Percent Positive". Johns Hopkins Bloomberg School of Public
Health. Retrieved from https://www.jhsph.edu/ covid-19/articles/covid-19-testing-understandingthe-percent- positive.html

El Tiempo. (2020, July 10). El debate en el Valle por el medicamento para COVID. Retrieved from https://www.eltiempo.com/colombia/cali/dudaspor-medicamento-ivermectina-para-pacientes-concoronavirus -516180

Food and Drug Administration. (2020). COVID-19 Frequently Asked Questions. Retrieved from https:// www.fda.gov/emergency-preparedness-andresponse/coronavirus-disease-2019-covid-19/covid19-frequently-asked-questions

González, R. (2020, May 05). "Se ha logrado aplanar la curva en Medellín más de lo hecho en América Latina”. Diario La República. Retrieved from https://www.larepublica.co/especiales/ como-las-regiones-enfrentan-el-covid-19/se-halogrado-aplanar-la-curva-dentro-de-medellin-masde-lo-hecho-en-america-latina-3001246

Jiménez, L. R. (2020). ¿Qué pasó en Medellín que iba tan bien con el manejo de la pandemia?. El Tiempo. Retrieved from https://www.eltiempo. $\mathrm{com} / \mathrm{colombia/medellin/coronavirus-en-}$ medellin-incremento-acelerado-de-casos-decovid-19-517238

Kapucu, N. (2005). Interorganizational coordination in dynamic context: Networks in emergency response management. Connections, 26(2), 33-48.

Kolster, N. (2020, September 09). Coronavirus en Venezuela: el lucrativo negocio de los que ayudan a cruzar las fronteras cerradas para regresar al país. BBC News. Retrieved from https://www.bbc.com/ mundo/noticias-america-latina-54066723

Koppell, J. G. (2010). Administration without borders. Public Administration Review, 70(s1), s46-s55.

La Silla Vacia (2020b). La patraseada de Claudia Lopez en su idea de apagar la economía. Retrieved from https://lasillavacia.com/patraseada-claudialopez-su-idea-apagar-economia-76639

López, C. (2020, April 29). Coronavirus, así va el apoyo a la gestión del Presidente. El Tiempo. Retrieved From https://www.eltiempo.com/politica/ gobierno/coronavirus-asi-va-el-apoyo-a-la-gestiondel-presidente-y-los-alcaldes- 490278 
Lynn, L. E., Jr., Heinrich, C. J., \& Hill, C. J. (2001). Improving governance: A new logic for empirical research. Washington, DC: Georgetown University Press.

Ministerio de Salud. (2020). Colombia cuenta actualmente con 5845 UCI. Retrieved from https:// www.minsalud.gov.co/Paginas/Colombia-cuentaactualmente-con-5845-UCI-.aspx

Ministerio de Salud y Protección Social. (2016). Redes Integrales de prestadores de servicios de salud: Lineamientos para el Proceso de Conformación, Organización, Gestión, Seguimiento y Evaluación. Bogota, DC: Author.

Osorio, C. H. (2020, February 03). Claudia Lopez le apuesta a un concejo de aliados sin puestos. $\mathrm{La}$ Silla Vacia. Retrieved from https://lasillavacia.com/ claudia-lopez-le-apuesta-concejo-aliados-sinpuestos- 75383

Pumarejo, J. (2020). Le ganamos la primera batalla al COVID, no la guerra. El Tiempo. Retrieved from https://www.eltiempo.com/colombia/barranquilla/ barranquilla-jaime-pumarejo-explica-comollegaron-y-superaron-el-pico-del-coronaviruscolombia-524974

Ramirez de la Cruz, E., Sanabria, P., Grin, E., Cravacuore, D., \& Orellana, A. (2020). The transactions costs of the government's response to the Covid-19 in Latin America. Public Administration Review, 80(4), 683-695.

Sanabria, P. (2015). Decentralization and Intergovernmental Relations in Colombia: Topics for a State Still in Quest of Structure and Capacity. Hemisphere, 24(1), 32-35.

Sanabria, P. (2017). Construcción de Gobernabilidad y Capacidad Institucional para la Renovación Urbana: Análisis del Modelo de Gobernanza y Descentralización de Medellín. In E. J. Grin, J. H. Bonivento \& F. L. Abrucio (Eds.), El Gobierno de las Ciudades: Análisis de los Modelos de Gobernanza y Descentralización de las Metrópolis Latinoamericanas. Caracas, Venezuela: CLAD.

Sanabria, P. (2019). Las Capacidades Institucionales de los Municipios Colombianos. In E. J. Grin, A. Carrera-Hernández F. L. Abrucio (Eds.), Capacidades Estatales en Gobiernos Locales Iberoamericanos. Actualidad, Brechas y Perspectivas. São Paulo, SP: Editora FGV.
Sanabria, P. (2020). Covid-19: Una prueba ácida a la capacidad de Estados, gobiernos y sociedades. Recomendaciones de Gestión y Políticas Públicas para una respuesta integral coordinada (Apuntes de Gestión y Políticas Públicas No. 1). Bogotá, D.C.: Escuela de Gobierno Universidad de los Andes.

Sanabria, P. (Forthcoming). Modernización de la Gestión Pública en Colombia: Coyunturas Críticas y Dependencia del Sendero en un Proceso No Lineal. In S. Leyva, \& S. Leyva (Eds.), El Estado del Estado. Antología de la Administración Pública Colombiana. Bogotá, DC: Ediciones Uniandes.

Semana. (2020a, June 04). "El presidente cuenta con mi apoyo, pero no con mi pleitesía": Claudia López. Retrieved from https://www.semana.com/nacion/ articulo/claudia-lopez-presidente-duque-cuentacon-mi-apoyo-pero-no-con-mi-pleitesia/676257

Semana. (2020b, March 25). Coronavirus: ¿Por qué Bogotá es la ciudad con más casos en el país? Retrieved from https://www.semana.com/vidamoderna/articulo/coronavirus-por-que-bogota-esla-ciudad-con-mas-casos-en-el-pais/659094

Semana. (2020c, May 19). Barranquilla otro foco de Covid-19 en la costa Caribe. Retrieved from https:// www.semana.com/nacion/articulo/barranquilla-elotro-foco-de-covid-19-en-la-costa-caribe/672493

Semana. (2020d, May 22). Cali, aumenta ocupación de camas UCI. Retrieved from https://www.semana. com/nacion/articulo/cali-aumenta-en-ocupacionde-camas-uci-y-casos-de-coronavirus/673509

Semana. (2020e, May 11). En Cali hubo fiestas, riñas y asesinatos en el día de la madre. Retrieved from https://www.semana.com/nacion/articulo/ en-cali-hubo-fiestas-rinas-y-asesinatos-en-dia-dela-madre/670482

Semana. (2020f, May 07). Las claves de Medellín para controlar el coronavirus, según su alcalde. Retrieved from https://www.semana.com/semana-tv/semanaen-vivo/articulo/las-claves-de-medellin-paracontrolar-el-coronavirus-segun-su-alcalde/669773

Semana. (2020g, Frebruary 18). Los Char la poderosa familia de la que habla Aida Merlano. Retrieved from https://www.semana.com/nacion/articulo/ los-char-la-poderosa-familia-de-la-que-habla-aidamerlano/652445

Semana. (2020h, May 12) ¿Cuáles laboratorios privados hacen pruebas covid-19 y cuánto cuesta?. 
Retrieved from https://www.semana.com/ semana-tv/semana-noticias/articulo/coronavirusen-colombia-cuales-laboratorios-privados-hacenpruebas/670704

Sostenibilidad Semana. (2020, April 26). Amazonas acechado por el Covid-19 de sus países vecinos. Retrieved from https://sostenibilidad.semana.com/ actualidad/articulo/coronavirus-en-colombiaamazonas-acechado-por-el-covid-19-de-sus-paisesvecinos/50345

Uran, O. (2010). Medellín Participatory Creativity in a Conflictive City. In J. Pearce (Ed.), Participation and democracy in the twenty-first century city (pp. 127-153). London, UK: Palgrave Macmillan.
Vanguardia. (2020, May 17). Avanza el traslado de pacientes del Amazonas que requieren UCI. https:// www.vanguardia.com/colombia/avanza-el-trasladode-pacientes-del-amazonas-que- requieren-uciGB2377967

Velásquez, T., \& Molinares, C. (2020). Así se estrelló Barranquilla contra el COVID 19. Heinrich Boll Stiftung. Retrieved from https://co.boell.org/es/2020/08/04/asise-estrello-barranquilla-contra-el-covid-19

Zamudio, R. M., \& Barar, F. (2014). Looking for the creative city: urban development through education and cultural strategies in Medellin, Colombia. In Proceedings of The Idea of the Creative City, Cracow, Poland.

\section{Ricardo Bello-Gomez}

https://orcid.org/0000-0001-6479-4979

Ph.D. in Public Affairs from the O'Neill School of Public and Environmental Affairs, Indiana University; Assistant Professor in the Department of Political Science, Texas Tech University. E-mail: rbellogo@ttu.edu

\section{Pablo Sanabria-Pulido}

https://orcid.org/0000-0003-0962-8489

Ph.D. in Public Administration and Policy from American University in Washington, D.C.; Associate professor at the School of Government of Universidad de los Andes, Colombia; Affiliate professor at Centro de Investigación y Docencia Económica (CIDE), Public Administration Division, México. E-mail: psanabri@uniandes.edu.co 